University of Nebraska - Lincoln

DigitalCommons@University of Nebraska - Lincoln

USDA National Wildlife Research Center - Staff Publications
U.S. Department of Agriculture: Animal and Plant Health Inspection Service

July 1999

\title{
Resource partitioning between coyotes and swift foxes: space, time, and diet
}

Ann M. Kitchen

Utah State University, Logan, UT

Eric M. Gese

Utah State University, eric.gese@usu.edu

Edward R. Schauster

Utah State University, Logan, UT

Follow this and additional works at: https://digitalcommons.unl.edu/icwdm_usdanwrc

Part of the Environmental Sciences Commons

Kitchen, Ann M.; Gese, Eric M.; and Schauster, Edward R., "Resource partitioning between coyotes and swift foxes: space, time, and diet" (1999). USDA National Wildlife Research Center-Staff Publications. 635.

https://digitalcommons.unl.edu/icwdm_usdanwrc/635

This Article is brought to you for free and open access by the U.S. Department of Agriculture: Animal and Plant Health Inspection Service at DigitalCommons@University of Nebraska - Lincoln. It has been accepted for inclusion in USDA National Wildlife Research Center - Staff Publications by an authorized administrator of DigitalCommons@University of Nebraska - Lincoln. 


\title{
Resource partitioning between coyotes and swift foxes: space, time, and diet
}

\author{
Ann M. Kitchen, Eric M. Gese, and Edward R. Schauster
}

\begin{abstract}
In its current distribution and abundance, the swift fox (Vulpes velox) has been significantly reduced from its historic range. A possible cause is competition with, and predation by, coyotes (Canis latrans). We investigated the level of spatial, temporal, and dietary resource use overlap between swift foxes and coyotes at the Pinon Canyon Maneuver Site in southeastern Colorado. We captured and radio-tracked 73 foxes and 24 coyotes from April 1997 to August 1998. We collected 10832 and 5350 locations of foxes and coyotes, respectively. Overall, home-range sizes of foxes and coyotes were $7.6 \pm 0.5$ (mean $\pm \mathrm{SE}$ ) and $19.8 \pm 1.9 \mathrm{~km}^{2}$, respectively. A high degree of interspecies spatial overlap was apparent, with fox home ranges being overlapped by coyote home ranges by as much as $100 \%$ and coyote sign (tracks and scats) being evident in all swift fox home ranges. There was no evidence of temporal avoidance of coyotes in fox movement patterns. Coyotes traveled significantly farther than foxes during diurnal hours; foxes spent the majority of diurnal hours in or on top of dens. Coyotes and foxes showed a high index of overlap for dietary resources, although some dietary partitioning was apparent. Swift foxes specialized in small prey, such as insects and rodents, while coyotes used greater proportions of large prey, such as lagomorphs and ungulates. Interference competition was evident, with $48 \%(12 / 25)$ of fox mortalities identified as confirmed or probable coyote-caused deaths. In each case, death occurred outside either the fox's home range or the $85 \%$ isopleth of that range, indicating that coyotes are more likely to attack a fox successfully when it is a substantial distance from a den. We propose that swift foxes are able to coexist with coyotes, owing to year-round den use and a degree of dietary partitioning.

Résumé : La répartition et l'abondance du Renard véloce (Vulpes velox) ont subi une diminution importante au cours des années. Parmi les causes possibles, il faut mentionner la compétition et la prédation exercées par le Coyote (Canis latrans). Nous avons tenté de déterminer l'importance du chevauchement des ressources spatiales, temporelles et alimentaires des deux espèces à Pinon Canyon Maneuver Site, dans le sud-est du Colorado. Nous avons capturé et suivi par radiotélémétrie 73 renards et 24 coyotes d'avril 1997 à août 1999. Par la suite, nous avons repéré les renards 10832 fois et les coyotes, 5350 fois. Dans l'ensemble, les domaines des renards ont été évalués à 7,6 $\pm 0,5$ (moyenne \pm erreur type) $\mathrm{km}^{2}$ et ceux des coyotes à $19,8 \pm 1.9 \mathrm{~km}^{2}$. Nous avons mesuré un chevauchement interspécifique important de l'espace utilisé et les domaines des renards étaient couverts par ceux des coyotes parfois à 100\%; nous avons trouvé des marques de la présence de coyotes (pistes, fèces) dans tous les domaines des renards. Les déplacements des renards ne permettent pas d'affirmer qu'il y a ségrégation temporelle des deux espèces. Les coyotes couvrent des distances significativement plus grandes que les renards durant les heures de jour, alors que les renards passent la plus grande partie des heures de jour dans ou sur leur terrier. Les ressources alimentaires des coyotes et des renards se recoupent largement, mais il se fait quand même un certain partitionnement. Les renards s'attaquent surtout à des petites proies, insectes et rongeurs, alors que les coyotes utilisent une proportion plus grande de proies de grande taille, lagomorphes et ongulés. Il se fait de la compétition d'interférence puisque $48 \%$ (12/25) des cas de mortalité observés chez les renards ont pu être attribués de façon probable ou certaine aux coyotes. De ces mortalités, toutes se sont produites à l'extérieur du domaine du renard ou au-delà de l'isoplèthe marquant les $85 \%$ du domaine, ce qui indique que les coyotes sont plus susceptibles d'attaquer un renard à une bonne distance de son terrier. Les Renards véloces sont probablement capables de cohabiter avec les coyotes parce qu'ils utilisent leur terrier l'année durant et qu'il y a partitionnement des ressources alimentaires.
\end{abstract}

[Traduit par la Rédaction]

\section{Introduction}

The swift fox (Vulpes velox) is a small carnivore ranging historically from northern Texas to southern Canada, including most of central North America (Banfield 1974; Egoscue
1979). The distribution and abundance of the swift fox underwent a widespread reduction in the 19th and early 20th centuries, mainly as a result of human impact, such as habitat modification and predator-control activities that were intended for coyotes (Canis latrans) and wolves (Canis

Received April 15, 1999. Accepted July 12, 1999.

A.M. Kitchen and E.R. Schauster. Department of Fisheries and Wildlife, Utah State University, Logan, UT 84322, U.S.A. E.M. Gese. ${ }^{1}$ National Wildlife Research Center, Department of Fisheries and Wildlife, Utah State University, Logan, UT 84322, U.S.A.

${ }^{1}$ Author to whom all correspondence should be addressed (e-mail: egese@cc.usu.edu). 
lupus). There is speculation that a major factor in the population dynamics of the swift fox continues to be competition with, and predation by, coyotes (Scott-Brown et al. 1987).

An understanding of the level of resource overlap between swift foxes and coyotes will enhance our knowledge of the interactions between these species. Numerous studies have documented the limiting of the distribution and abundance of smaller carnivore species by competitively dominant carnivores. For example, red foxes (Vulpes vulpes) have restricted ranges when they are sympatric with coyotes (Voigt and Earle 1983; Sargeant et al. 1987), and coyotes are killed by wolves and will often avoid areas of high wolf abundance (Fuller and Keith 1981; Carbyn 1987). Frame (1986) found competition to be common among carnivores in the Serengeti ecosystem in Tanzania, noting examples of direct interference competition, cleptoparasitism, and competitive exclusion. Numerous studies have suggested that interspecific competition with larger carnivores, such as the hyena (Crocuta crocuta) and lion (Panthera leo), is a factor limiting wild dog (Lycaon pictus) density in eastern Africa (Kruuk 1972; Mills and Biggs 1993; Creel and Creel 1996).

The extent of spatial overlap between sympatric species largely determines the potential for competition for all resources. While the extent of spatial overlap between swift foxes and coyotes has not been documented, the relationship between space use by coyotes and by other fox species has been studied. Red foxes establish home ranges outside those of coyotes, even when the coyote territory is in an area suitable as fox habitat (Voigt and Earle 1983; Harrison et al. 1989). Conversely, Wooding (1984) found that gray fox (Urocyon cinereoargenteus) home ranges were substantially or entirely overlapped by coyote home ranges in Alabama and Mississippi. White et al. (1994) reported that coyote home ranges overlapped (both spatially and temporally) all kit fox (Vulpes macrotis) home ranges by $>30 \%$, some fox home ranges being entirely overlapped by coyote ranges.

Dietary overlap can also lead to interspecific competition. There is little documented information on dietary resource partitioning between coyotes and swift foxes. White et al. (1995) reported a high degree of dietary overlap (Horn's index $=0.85$ ) between coyotes and kit foxes in California, although dietary specializations were apparent, with kit foxes consuming higher proportions of small prey such as rodents and birds. Coyotes ate higher proportions of large prey such as leporids and feral pigs. Similarly, Cypher and Spencer (1998) reported a high degree of overlap in the use of prey items by coyotes and kit foxes in California.

Evidence of coyote-caused fox mortalities has been reported in several studies and is generally believed to constitute interference competition as opposed to predation, owing to the lack of consumption of the fox carcass by the coyote (Sargeant and Allen 1989; Cypher and Spencer 1998; Sovada et al. 1998). Coyotes can cause $>65 \%$ of fox deaths (Cypher and Scrivner 1992; Ralls and White 1995). Reintroduced populations of swift foxes in Canada were heavily impacted by coyotes, with coyotes being the greatest single cause of fox deaths (Carbyn et al. 1994). Coyotes appear to be a significant cause of mortality of both adult and juvenile swift foxes at the Pinon Canyon Maneuver Site (PCMS) in southeastern Colorado (Rongstad et al. 1989; Covell 1992).
Further evidence of the impact of coyotes on swift fox populations comes from several studies in which increases in fox numbers following coyote-removal or -control programs have been reported (Kilgore 1969; Linhart and Robinson 1972; Covell 1992, Henke 1992).

Investigations of resource overlap and interactions between species may provide insight into the mechanisms of sympatry that are operating. These mechanisms act to decrease either exploitative competition, by resource partitioning (Schoener 1974), or interference competition, by avoidance (Case and Gilpin 1974), to facilitate coexistence with a dominant or predatory species. Red foxes avoid coyotes by establishing ranges that abut but do not overlap those of coyotes (Major and Sherburne 1987). Gray foxes are able to coexist spatially with coyotes through habitat segregation and their ability to climb trees to escape from coyotes (Wooding 1984). White et al. (1994) suggested that kit foxes are able to survive in coyote home ranges by utilizing certain prey species more efficiently than coyotes do, and by establishing a number of dens to facilitate escape. Similarly, current information on swift fox behavior indicates that den use may be an important mechanism allowing for sympatry with coyotes (South Dakota Department of Game, Fish and Parks 1998). Swift foxes use dens year-round and have been described as the most subterranean of all the North American canids (Scott-Brown et al. 1987).

Understanding the factors presently impacting swift fox populations is essential to the development of effective management strategies and recovery efforts. A high level of resource overlap with coyotes could indicate the potential for exploitative competition (Case and Gilpin 1974; Polis et al. 1989) and, in conjunction with interference competition, could significantly impact swift fox populations (Carbyn 1986; Scott-Brown et al. 1987). In this study, the influence of coyotes on swift fox populations is examined and the potential for exploitative competition is investigated by determining the extent of spatial, temporal, and dietary resource overlap between the two canid species. Interference competition was also documented in the form of coyote-caused fox mortalities.

\section{Methods}

The study area was located on the $1040-\mathrm{km}^{2}$ PCMS in Las Animas County, Colorado. The climate is semi-arid, mean annual precipitation ranging between 26 and $38 \mathrm{~cm}$. Mean monthly temperatures range from $-1{ }^{\circ} \mathrm{C}$ in January to $23^{\circ} \mathrm{C}$ in July. Elevations range from 1310 to $1740 \mathrm{~m}$ asl. The site consists of river canyons, limestone breaks, and open plains. The two main vegetation types are shortgrass prairie and pinyon pine (Pinus edulis) - juniper (Juniperus monosperma) communities (Shaw et al. 1989). The study area was primarily used for cattle ranching prior to 1982 , during which period predator populations (mostly coyotes and swift foxes) were trapped and hunted. In 1982 the U.S. Army acquired PCMS for military activities that involves month-long mechanized training sessions 3-4 times a year. Coyote removal on PCMS was prohibited from 1983 to 1986. In 1987 and 1988, coyotes on the southwestern third of the site were controlled (Gese and Rongstad 1989). Since then there has been no intensive removal, although occasional shooting of coyotes by hunters has oc- 
curred. Trapping and hunting of coyotes continues on the ranches surrounding the study area.

Coyotes were captured by aerial net-gunning from a helicopter (Barrett et al. 1982; Gese et al. 1987). Each coyote was ear-tagged, aged by tooth wear (Gier 1968), sexed, weighed, and radiocollared. Swift foxes were captured using box traps baited with chicken (Covell 1992). Trap-enclosure systems, in which a fox den is enclosed by a fence with exits into box traps, were employed to recapture specific foxes (Covell 1992). Each fox was sexed, aged by tooth wear and body size (Rongstad et al. 1989), ear-tagged, weighed, and radio-collared with a 30- to 50-g transmitter (Advanced Telemetry Systems, Isanti, Minn.). Transmitter mass was $<5 \%$ of the body mass of the animal (Eberhardt et al. 1982). Foxes were considered to be juveniles until the breeding season following their birth. All other foxes were considered to be adults. All coyotes captured were aged as $>1$ year old, and thus all were considered to be adults. All radio collars included a mortality sensor that activated after $6 \mathrm{~h}$ of no motion. All coyotes and foxes were released at the site of capture.

We attempted to locate radio-collared coyotes and foxes daily. Locations were obtained by triangulating $2-3$ bearings of the animals' positions in $<10 \mathrm{~min}$. Triangulation angles were maintained between $20^{\circ}$ and $160^{\circ}$ (Gese et al. 1988a). Animals' positions were determined using the software package Locate (Pacer, Truro, N.S.). Telemetry error was determined with reference transmitters to be $\pm 8^{\circ}$. We attempted to obtain an equal number of locations in all time periods throughout the day $(24 \mathrm{~h})$ to reduce bias in home range size estimates (Gese et al. 1990). Point locations were taken at $\geq 8$-h intervals and sequential locations were taken every $0.5 \mathrm{~h}$. Aerial telemetry (Mech 1983) was employed to locate missing animals. When foxes were located in a den, the den location was recorded and marked. Foxes were considered to belong to the same social group if they used the same area and dens concurrently. Coyotes were considered to belong to the same pack if they occupied the same territory (Gese et al. 1988b).

Sequential and point locations were used to determine homerange size (Gese et al. 1990) and spatial distribution. Sequential locations were also used to determine activity patterns. Home-range size and spatial overlap were determined using the Calhome homerange analysis program (Kie et al. 1996) and Arcview 3.0 (Environmental Systems Research Institute, Inc., Redlands, Calif.). Home-range sizes were calculated using the $95 \%$ adaptive kernel method (Worton 1989). Home-range size was calculated for each individual and not for each social group, owing to changes in socialgroup composition due to mortalities and dispersal and in order to determine variation between individuals within a social group. Home-range sizes were calculated only for animals with $>35$ locations per season. For the purpose of analyses, we defined seasons on the basis of energetic demands (due to climatic changes and prey abundance) and behavioral characteristics (including breeding, gestation, pup rearing, and dispersal) that were applicable to both coyotes and swift foxes: pup-rearing season (15 April - 14 August), dispersal season (15 August - 14 December), and breedinggestation season (15 December - 14 April). Unless otherwise stated, data from the pup-rearing seasons in 1997 and 1998 were combined for analysis.

We used radiotelemetry data to determine if swift fox movement patterns showed spatial-temporal avoidance of coyotes (White et al. 1994). All sympatric pairs of coyotes and foxes (a pair consisted of one coyote and one fox) were used in the analysis. For these sympatric pairs, the average distance between the locations of the coyote and the fox taken concurrently (within a 6-h time span) was compared with the separation distance expected by chance. The separation distance expected by chance was calculated by averaging all pairs of locations taken with $>6 \mathrm{~h}$ between locations, this being the distance expected if the coyote and the fox were moving independently of each other. Students' $t$ test was used to compare the average distance between locations of a coyote-fox sympatric pair (the sample unit) taken concurrently ( $<6 \mathrm{~h}$ apart) with that expected by chance (distance between locations $>6 \mathrm{~h}$ apart). Avoidance was indicated if the distance between locations taken concurrently was significantly greater than that expected by chance. This analysis was performed separately for diurnal (06:0018:00) and nocturnal (18:00-06:00) locations, to clarify the effect of den use on spatial-temporal relationships between swift foxes and coyotes. Spatial-temporal relationships of coyote-coyote pairs living in the same coyote pack and fox-fox pairs living in the same social group were analyzed for each season, using the methodology described above. As these pairs were taken from within social groups, the results are expected to show attraction within the pairs, and were used to evaluate the validity of the analysis.

Sequential tracking was used to assess the activity patterns of coyotes and foxes. The mean distance traveled per hour $(\mathrm{km} / \mathrm{h})$ was used in statistical comparisons. Distances traveled during dawn (05:00-09:00), day (09:00-17:00), evening (17:00-21:00), and night $(21: 00-05: 00)$ and overall $(24 \mathrm{~h})$ were compared between seasons for coyotes and foxes, using analysis of variance. Distances traveled during dawn, day, evening, and night and overall were compared between species, using Students' $t$ test.

Dietary overlap between the two species was examined using scat analysis. Scats were collected monthly along transects and associated roads and in the vicinity of fox dens. Scats were ovendried for $\geq 24 \mathrm{~h}$ before analysis. Skeleton and hair reference collections and hair keys (Moore et al. 1974) were used to identify food items. The frequency of occurrence and percent volume of the different food items in each scat were recorded. Percent volume of food items was estimated visually to the nearest $5 \%$. The frequency of occurrence of prey items was calculated by recording the presence or absence of the item in a scat. Only prey items constituting $>20 \%$ of the volume were included, to minimize the likelihood of overestimating small prey (Martin et al. 1946; Weaver and Hoffman 1979). The frequencies of occurrence of prey items were combined into 4 categories, mammal, insect, vegetation, and other, for statistical analysis. Vegetative material was counted only if it was contained within the scat. For analysis of prey-size preferences, mammal species were divided into size classes based on prey mass. Size classes included rodents $(<0.5 \mathrm{~kg})$, cottontail rabbits $(0.5-1.5 \mathrm{~kg})$, jackrabbits $(1.5-4 \mathrm{~kg})$, and ungulates $(>4 \mathrm{~kg})$. Horn's similarity index (Horn 1966) was used to calculate dietary overlap between the species. Shannon's diversity index (Colwell and Futuyma 1971) was used to estimate the dietary diversity of the two species. Student's $t$ test was used to compare differences in diversity between coyotes and foxes. Overall and seasonal differences in diet between the two canids were calculated using $\chi^{2}$ analysis with Statistical Analysis Systems (SAS Institute Inc. 1988).

Mortality rates were determined using radio-collared foxes and coyotes. The location of the carcass was recorded and the site inspected for tracks and sign. The cause of death was determined via necropsy. Tooth-puncture wounds, hemorrhaging, and muscle injuries were used to identify predator-caused mortality. Seasonal and annual survival rates were estimated following Trent and Rongstad (1974), missing individuals being censored during the season in which they went missing for seasonal survival analysis, and censored altogether for annual survival analysis, following procedures recommended by White and Garrott (1990). The location of death of suspected and confirmed coyote-killed foxes was analyzed relative to the fox's home-range boundary by plotting all isopleths of the fox home range to the nearest $5 \%$ isopleth. The location of death of the fox was then assessed relative to these isopleths (if the location of death was inside the fox home range) and the distance to the closest known den currently in use (used in the season in which death occurred) by the fox was calculated. The average dis- 
Fig. 1. Spatial organization and home-range overlap of coyotes and swift foxes during the pup-rearing season 1997 (A), dispersal season 1997 (B), breeding season 1998 (C), and pup-rearing season 1998 (D) on Pinon Canyon Maneuver Site, Colorado.
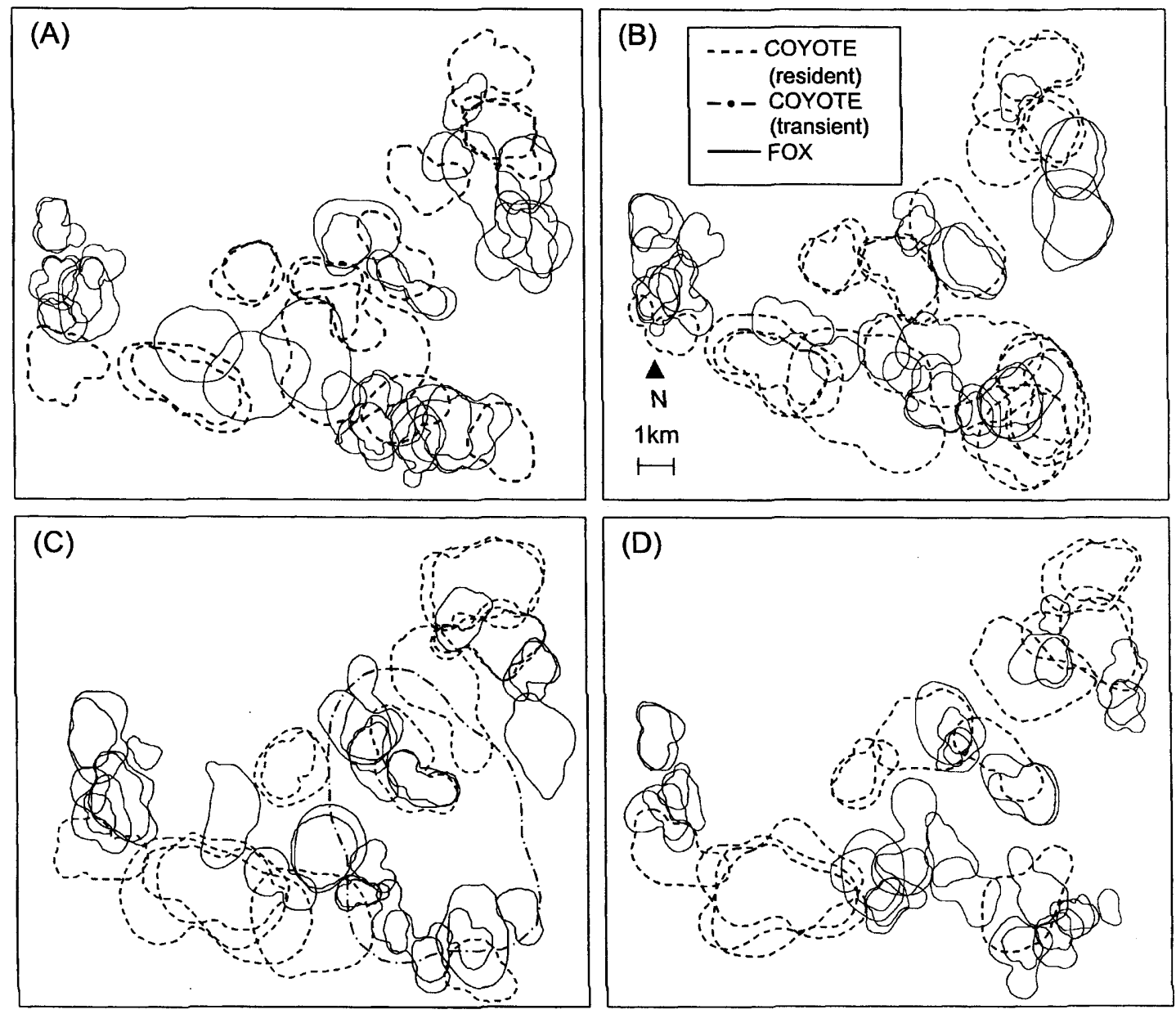

tance of all telemetry locations of coyote-killed foxes to their closest known den currently in use (used by the fox in the season of location) was also calculated.

\section{Results}

Twenty-four coyotes (10 female, 14 male) from 14 packs were radio-collared during the study. Sixteen coyotes were captured in March 1997; 4 were tracked for 3-7 months and 12 until August 1998 (17 months). Eight coyotes were captured in August 1997 and tracked until August 1998 (12 months). All coyotes were residents at the time of capture and all but one remained so throughout the study. One male coyote moved from the original home range it occupied with its mate during the pup-rearing and dispersal seasons in 1997, became transient during the breeding season, and established a new resident home range in the puprearing season in 1998. Seventy-three foxes ( 38 female, 35 male) from 30 social groups were captured between January 1997 and August 1998. Six foxes were tracked for $\leq 1$ month, 24 for 1-6 months, 17 for 7-12 months, and 26 for 13-20 months.

\section{Spatial relations}

We obtained 5350 locations (1184 in the pup-rearing season in 1997, 1576 in the dispersal season in 1997, 1099 in the breeding season in 1998, and 1491 in the pup-rearing

season in 1998) of radio-collared coyotes from 15 April 1997 to 15 August 1998. For coyotes with sufficient numbers of points for calculating home-range size, the mean number of locations obtained per coyote each season was $83.9 \pm 3.3$ (mean $\pm \mathrm{SE}$ ). The mean seasonal home range sizes for coyotes did not differ significantly between males $\left(18.6 \pm 1.5 \mathrm{~km}^{2}\right)$ and females $\left(16.6 \pm 2.6 \mathrm{~km}^{2}\right)(t=0.57$, $\mathrm{df}=20, P>0.05)$. The mean home range sizes for coyotes in the pup-rearing, dispersal, and breeding seasons were $16.7 \pm 2.2 \mathrm{~km}^{2}(n=16), 17.3 \pm 2.2 \mathrm{~km}^{2}(n=20)$, and $17.7 \pm$ $3.1 \mathrm{~km}^{2}(n=12)$, respectively. Coyote home range size did not vary significantly between seasons $\left(F_{[2]}=0.04, P>\right.$ 0.05). The overall (April 1997 - August 1998) home-range size for coyotes was $19.8 \pm 1.9 \mathrm{~km}^{2}$ (mean $\left.\pm \mathrm{SE}\right)$. Only resident coyotes were included in home range size analyses. The one male coyote that experienced a period of transiency maintained a home range of $15.0 \mathrm{~km}^{2}$ during the 1997 puprearing season, $12.0 \mathrm{~km}^{2}$ during the dispersal season, and $117.5 \mathrm{~km}^{2}$ during the breeding season, and in the 1998 puprearing season established a new home range of $14.5 \mathrm{~km}^{2}$ (Fig. 1). Coyotes were located in all habitat types in the study area, including river canyons, pinyon pine - juniper communities, and open plains.

We obtained 10832 locations (2221 in the pup-rearing season in 1997, 3190 in the dispersal season in 1997, 2454 in the breeding season in 1998, and 2967 in the pup-rearing 
Table 1. Separation distances between coyote and swift fox sympatric pairs on the Pinon Canyon Maneuver Site, Colorado, April 1997 August 1998.

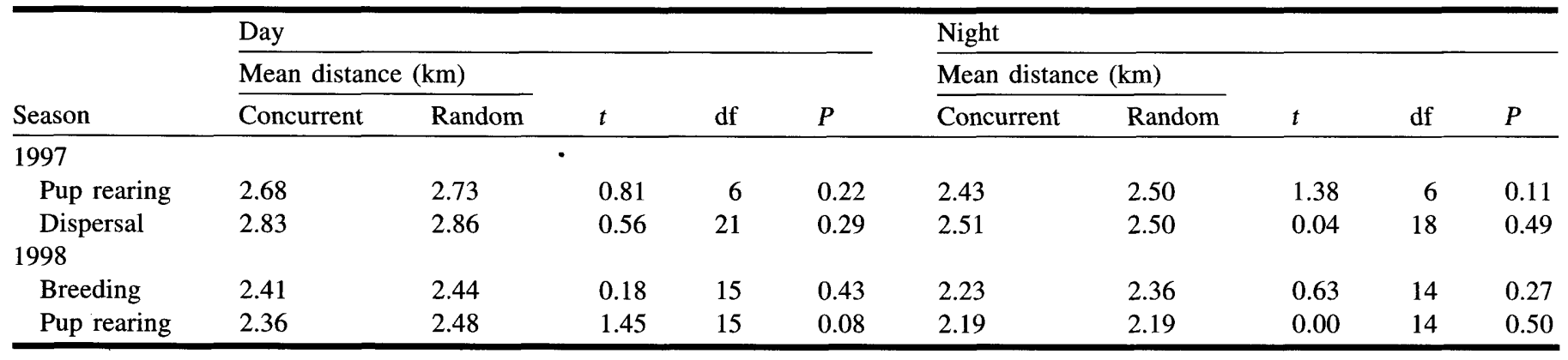

Table 2. Separation distances between swift fox - swift fox sympatric pairs on the Pinon Canyon Maneuver Site, Colorado, April 1997 August 1998.

\begin{tabular}{|c|c|c|c|c|c|c|c|c|c|c|}
\hline \multirow[b]{3}{*}{ Season } & \multicolumn{5}{|l|}{ Day } & \multicolumn{5}{|l|}{ Night } \\
\hline & \multicolumn{2}{|c|}{ Mean distance $(\mathrm{km})$} & \multirow[b]{2}{*}{$t$} & \multirow[b]{2}{*}{ df } & \multirow[b]{2}{*}{$P$} & \multicolumn{2}{|c|}{ Mean distance $(\mathrm{km})$} & \multirow[b]{2}{*}{$t$} & \multirow[b]{2}{*}{ df } & \multirow[b]{2}{*}{$P$} \\
\hline & Concurrent & Random & & & & Concurrent & Random & & & \\
\hline Pup rearing & 0.42 & 0.95 & 4.34 & 4 & 0.01 & 0.91 & 1.20 & 3.03 & 4 & 0.04 \\
\hline Dispersal & 0.58 & 0.91 & 3.44 & 4 & 0.02 & 1.14 & 1.55 & 3.31 & 4 & 0.03 \\
\hline \multicolumn{11}{|l|}{1998} \\
\hline
\end{tabular}

season in 1998) of radio-collared foxes from 15 April 1997 to 15 August 1998. For foxes with sufficient numbers of points for calculating home-range size, the mean number of locations obtained per fox each season was $80.8 \pm 2.6$ (mean \pm $\mathrm{SE}$ ). The seasonal home-range sizes for foxes did not differ significantly between males $\left(5.4 \pm 0.4 \mathrm{~km}^{2}\right)$ and females $\left(5.3 \pm 0.5 \mathrm{~km}^{2}\right)(t=0.11$, df $=53, P>0.05)$. The homerange sizes for foxes in the pup-rearing, dispersal, and breeding seasons were $5.9 \pm 0.5 \mathrm{~km}^{2}(n=50), 7.7 \pm 0.6 \mathrm{~km}^{2}(n=30)$, and $6.7 \pm 0.6 \mathrm{~km}^{2}(n=31)$, respectively. Home-range sizes for foxes did not vary significantly between seasons $\left(F_{[2]}=\right.$ 2.18, $P>0.05$ ). The overall (April 1997 - August 1998) home-range size for foxes was $7.6 \pm 0.5 \mathrm{~km}^{2}$ (mean $\pm \mathrm{SE}$ ). Foxes were only located in open-plain habitat, even though trapping efforts were conducted in pinyon pine - juniper communities.

The average overall home-range size for coyotes was significantly greater than that for foxes $(t=6.30$, df $=24, P<$ $0.001)$. Swift fox home ranges were overlapped by coyote home ranges by as much as $100 \%$ (Fig. 1). Minimum and average home-range overlaps were not calculated, owing to an inability to incorporate the home ranges of uncollared coyotes into the analysis; however, all fox home ranges were believed to be completely overlapped by coyote territories. Coyote presence was recorded in all swift fox home ranges by telemetry locations, scent post station and activity-index visits (E.R. Schauster, unpublished data), scat deposition, and coyote sightings. Gese et al. (1989) provided further support for this conclusion with their observation that coyotes maintained home ranges that covered all of the PCMS study area between 1983 and 1986.

\section{Spatial-temporal relations}

The spatial-temporal avoidance of coyotes in swift fox activity patterns was investigated by comparing the mean distance between coyote-fox sympatric pairs when locations were taken concurrently with that expected by chance. The choice of a 6-h interval for use in the analysis was arbitrary, but the average time difference between paired locations was less than $1 \mathrm{~h} ;<20 \%$ of the paired locations were over $2 \mathrm{~h}$ apart. We calculated distances for 7 coyote-fox pairs in the 1997 pup-rearing season, 22 pairs in the dispersal season, 17 pairs in the breeding season, and 16 pairs in the 1998 puprearing season. Separation distances between the two canids did not differ from those expected by chance in any season, using either diurnal or nocturnal locations (Table 1).

The spatial-temporal analysis of fox-fox pairs showed that the mean distance between pairs when locations were taken concurrently was significantly less than that expected by chance during both diurnal and nocturnal periods in all seasons (Table 2). The spatial-temporal analysis of coyotecoyote pairs showed that the mean distance between pairs when locations were taken concurrently was significantly less than that expected by chance during diurnal and nocturnal periods in all seasons except the diurnal period in the breeding season (Table 3 ). These results demonstrate that the methodology had sufficient strength to show attraction between individuals in social groups.

\section{Activity patterns and movements}

The average distance traveled per hour by a coyote during a $24-\mathrm{h}$ period varied significantly among seasons $\left(F_{[2]}=\right.$ 9.42, $P<0.01$ ), the greatest rate of movement occurring in 
Table 3. Separation distances between coyote-coyote sympatric pairs on the Pinon Canyon Maneuver Site, Colorado, April 1997 August 1998.

\begin{tabular}{|c|c|c|c|c|c|c|c|c|c|c|}
\hline \multirow[b]{3}{*}{ Season } & \multicolumn{5}{|l|}{ Day } & \multicolumn{5}{|l|}{ Night } \\
\hline & \multicolumn{2}{|c|}{ Mean distance $(\mathrm{km})$} & \multirow[b]{2}{*}{$t$} & \multirow[b]{2}{*}{ df } & \multirow[b]{2}{*}{$P$} & \multicolumn{2}{|c|}{ Mean distance $(\mathrm{km})$} & \multirow[b]{2}{*}{$t$} & \multirow[b]{2}{*}{ df } & \multirow[b]{2}{*}{$P$} \\
\hline & Concurrent & Random & & & & $\overline{\text { Concurrent }}$ & Random & & & \\
\hline Pup rearing & 1.07 & 1.70 & 3.20 & 3 & 0.04 & 1.43 & 1.89 & 3.27 & 3 & 0.04 \\
\hline Dispersal & 0.99 & 1.61 & 9.29 & 4 & 0.00 & 0.79 & 1.53 & 4.53 & 4 & 0.01 \\
\hline \multicolumn{11}{|l|}{1998} \\
\hline
\end{tabular}

Fig. 2. Movement rates of coyotes and swift foxes over a 24-h period on the Pinon Canyon Maneuver Site, Colorado, April 1997 August 1998. Bars indicate standard error.

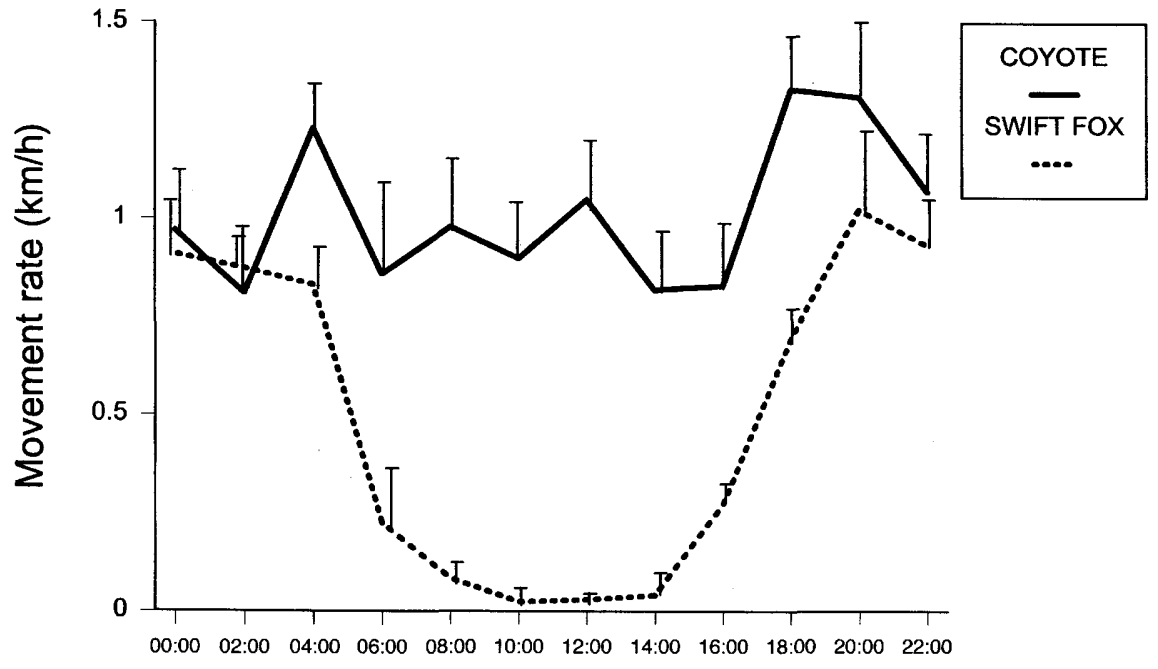

Time

the breeding season $(\bar{x}=1.43 \mathrm{~km} / \mathrm{h})$. The mean rate of movement by coyotes during a $24-\mathrm{h}$ period in the puprearing season was $0.84 \mathrm{~km} / \mathrm{h}$ and in the dispersal season was $0.89 \mathrm{~km} / \mathrm{h}$. The rate of movement by coyotes did not differ between males $(1.09 \pm 0.09 \mathrm{~km} / \mathrm{h})$ and females $(0.94 \pm$ $0.10 \mathrm{~km} / \mathrm{h})(t=1.16, \mathrm{df}=29, P>0.05)$. The distance traveled per hour by an adult swift fox during a 24-h period also varied significantly among seasons $\left(F_{[2]}=4.66, P<0.02\right)$, the greatest rate of movement occurring in the breeding season $(\bar{x}=0.90 \mathrm{~km} / \mathrm{h})$. The mean rate of movement of adult swift foxes during a $24-\mathrm{h}$ period in the pup-rearing season was $0.4 \mathrm{~km} / \mathrm{h}$ and in the dispersal season was $0.74 \mathrm{~km} / \mathrm{h}$. The mean rate of movement by adult swift foxes did not differ between males $(0.68 \pm 0.12 \mathrm{~km} / \mathrm{h})$ and females $(0.59 \pm$ $0.10 \mathrm{~km} / \mathrm{h})(t=0.63$, df $=34, P>0.05)$.

Activity patterns differed between the two species throughout the 24-h period (Fig. 2). Coyotes moved significantly farther per hour during the day than foxes in all seasons (pup-rearing season: $t=5.44$, df $=24, P<0.01$; dispersal season: $t=5.30$, df $=19, P<0.01$; breeding season: $t=7.61$, df $=11, P<0.01$ ). Diurnal activity of foxes occurred mainly in the vicinity of dens. Foxes were in or on top of dens for $85.6 \%$ of diurnal locations. Foxes used $6.44 \pm$ 0.9 dens per season (the maximum number of dens used per season was 14).
There was no significant difference in crepuscular movements between coyotes and foxes in any season except the pup-rearing season, when coyotes traveled farther per hour (pup-rearing season: dawn, $t=3.01$, $\mathrm{df}=28, P<0.01$; evening, $t=4.74$, df $=19, P<0.01)$. During the dispersal season (dawn: $t=2.07$, df $=8, P>0.05$; evening: $t=0.89$, $\mathrm{df}=17, P>0.05$ ) and breeding season (dawn: $t=1.53$, $\mathrm{df}=$ $8, P>0.16$; evening: $t=1.35, \mathrm{df}=12, P>0.05$ ) coyotes and foxes had similar activity patterns during the crepuscular time periods. Rates of movement during the night did not differ significantly between the two species in any season (pup-rearing season: $t=1.42$, df $=29, P>0.05$; dispersal season: $t=1.98$, df $=16, P>0.05$; breeding season: $t=$ 0.06 , df $=12, P>0.05$ ).

\section{Dietary partitioning}

We collected 659 swift fox scats and 469 coyote scats between April 1997 and August 1998. Prey items identified in both coyote and fox scats were insects (mainly Orthoptera), cottontail rabbits (Sylvilagus audubonii), black-tailed jackrabbits (Lepus californicus), rodents, pronghorn antelope (Antilocapra americana), birds, lizards, vegetation (including grass, seeds, and juniper berries), and garbage. Rodent species evident in coyote and fox diets were ground squirrels (Spermophilus spilosoma), black-tailed prairie dogs (Cynomys 
Fig. 3. Percent volume of food items in the diets of coyotes (A) and swift foxes (B) on the Pinon Canyon Maneuver Site, Colorado, April 1997 - August 1998. The months in which scat samples were not collected are denoted by //.

(A)
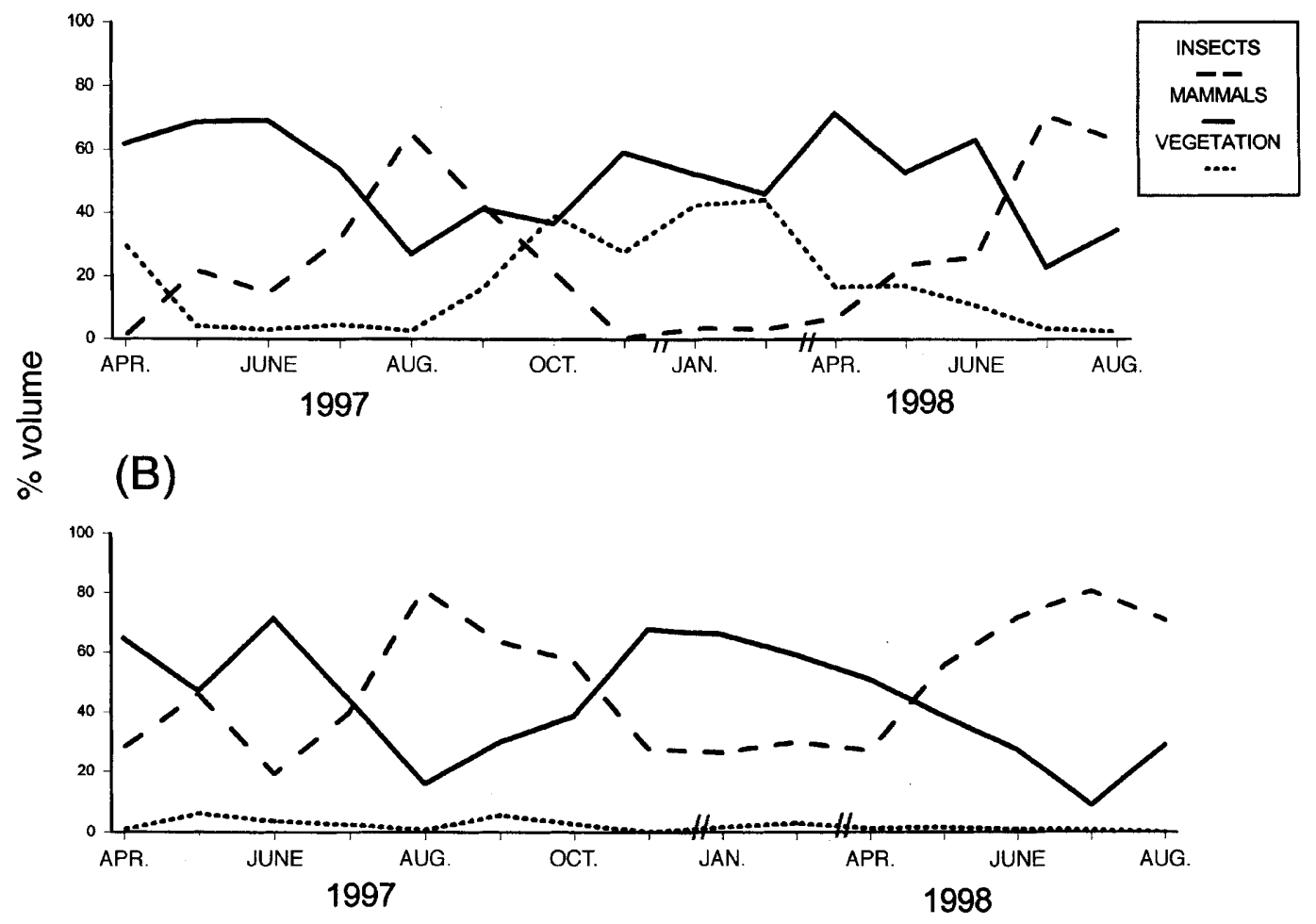

Fig. 4. Percent volume of mammalian food items in the diets of coyotes (A) and swift foxes (B) on the Pinon Canyon Maneuver Site, Colorado, April 1997 - August 1998. The months in which scat samples were not collected are denoted by //.

(A)

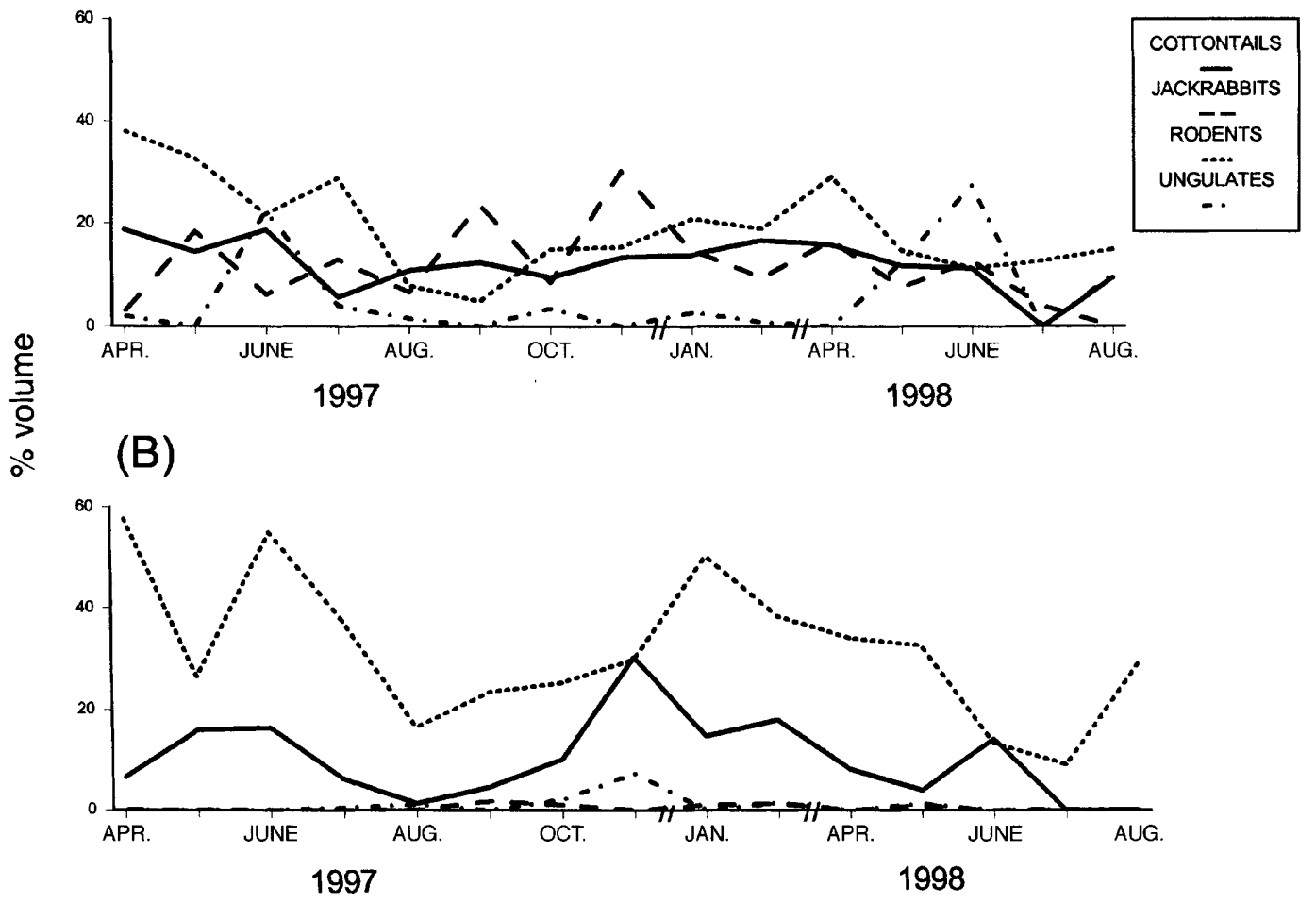


Table 4. Seasonal and overall (average of seasons) indices of dietary diversity (Shannon's index) and similarity (Horn's index) for coyotes and swift foxes on the Pinon Canyon Maneuver Site, Colorado, April 1997 - August 1998.

\begin{tabular}{llll}
\hline & \multicolumn{2}{l}{$\begin{array}{l}\text { Shannon's diversity } \\
\text { index }\end{array}$} & \\
\cline { 2 - 3 } & Coyote & Swift fox & $\begin{array}{l}\text { Horn's } \\
\text { similarity index }\end{array}$ \\
Season & 0.69 & 0.51 & 0.91 \\
Pup rearing & 0.67 & 0.46 & 0.80 \\
Dispersal & 0.60 & 0.57 & 0.71 \\
Breeding & 0.65 & 0.51 & 0.81 \\
Overall & 0.65 & \\
\hline
\end{tabular}

ludovicianus), pocket gophers (Pappogeomys castanops), pocket mice (Perognathus spp.), kangaroo rats (Dipodomys ordii), harvest mice (Reithrodontomys spp.), deer mice (Peromyscus spp.), grasshopper mice (Onychomys leucogaster), and wood rats (Neotoma spp.). This represented all the small rodent species available in the shortgrass prairie habitat on the PCMS, with the exception of the Colorado chipmunk (Eutamias quadrivittatus). Several coyote scats $(n=3)$ consisted solely $(100 \%)$ of swift fox remains (bones and teeth).

There were significant differences in the frequency of occurrence of prey items consumed among seasons for both coyotes $\left(\chi^{2}=101.45, \mathrm{df}=6, P<0.01\right)$ and swift foxes $\left(\chi^{2}=\right.$ $45.75, \mathrm{df}=6, P<0.01)$. Mammals constituted the major part of both coyote and fox diets from October to July (Figs. 3 and 4). Insects were consumed in a larger volume than any other prey item during August and September by both coyotes and foxes. Vegetation (mainly juniper berries) constituted a substantial portion of the diet of coyotes from October to April.

Horn's similarity index showed that the overall dietary overlap between coyotes and swift foxes was high (Table 4). However, $\chi^{2}$ tests revealed significant differences between the diets of coyotes and foxes in the pup-rearing $\left(\chi^{2}=39.39\right.$, $\mathrm{df}=3, P<0.001)$, dispersal $\left(\chi^{2}=63.10, \mathrm{df}=3, P<0.001\right)$, and breeding $\left(\chi^{2}=103.49\right.$, $\left.\mathrm{df}=3, P<0.001\right)$ seasons and overall $\left(\chi^{2}=109.86, \mathrm{df}=3, P<0.001\right)$. A significant difference was found in the amount of mammal prey of various sizes consumed by coyotes and foxes (Fig. 4). Coyotes consumed significantly higher proportions of larger mammals (ungulates and leporids, especially black-tailed jackrabbits) than smaller mammals (rodents) than did foxes in the puprearing $\left(\chi^{2}=43.79, \mathrm{df}=3, P<0.001\right)$, dispersal $\left(\chi^{2}=\right.$ 23.77, $\mathrm{df}=3, P<0.001)$, and breeding $\left(\chi^{2}=25.57, \mathrm{df}=3\right.$, $P<0.001)$ seasons and overall $\left(\chi^{2}=46.19, \mathrm{df}=3, P<\right.$ 0.001) (Table 5).

Dietary diversity was significantly greater for coyotes than for swift foxes in all seasons (Table 4) (pup-rearing season: $t=46.01, \mathrm{df}=380.20, P<0.001$; dispersal season: $t=$ 30.44 , df $=155.75, P<0.001$; breeding season: $t=4.49$, $\mathrm{df}=281.57, P<0.001$ ).

\section{Mortality}

Forty-eight percent $(12 / 25)$ of all fox mortalities and $80 \%$ (12/15) of mortalities of known cause were confirmed or suspected of being caused by coyotes (Fig. 5). Five male and seven female foxes were killed by coyotes. All foxes con- firmed or suspected of being killed by coyotes were found dead either outside the fox's home range (95\% isopleth) (6 of 11 ; 1 was killed before sufficient locations could be obtained for a home range to be generated) or outside the $85 \%$ isopleth of the range (5 of 11), using the adaptive kernel method. The location of death was $1.34 \pm 0.29 \mathrm{~km}$ (mean \pm SE) from the nearest currently used (used in the season of death) known den of the fox. This distance was significantly greater than the average distance of all fox locations from their nearest currently used den $(0.32 \pm 0.004 \mathrm{~km}$; mean \pm SE) $(t=3.66, \mathrm{df}=10, P<0.005)$ (Fig. 6). Because swift foxes were killed but generally not eaten by coyotes (i.e., were not prey items), we believe that coyotes were unlikely to have moved the fox carcass significantly. Thus, the locations of fox recoveries were considered to be the locations of the kills.

Seasonal survival rates for adult foxes were 0.92 (puprearing season), 0.91 (dispersal season), and 0.76 (breeding season). The annual survival rate for adult foxes (April 1997 - April 1998) was 0.64. The interval survival rates for juvenile foxes from capture date (captures occurred between 15 August and 28 November 1997) until 15 December (when they were considered adult) and until 14 April (completion of the breeding season) were $0.86(n=13)$ and $0.69(n=12)$, respectively.

The annual coyote survival rate for 1997 was 0.79 . There were four mortalities (two male and two female, all resident adults): two died in the dispersal season (one was shot and one died of an unknown cause) and two died in the puprearing season (one was shot and one died of an unknown cause).

\section{Discussion}

This study demonstrated that coyotes and swift foxes exhibit high levels of resource overlap. Coyote presence was evident in the home ranges of all foxes tracked. Foxes had lower spatial requirements than coyotes, maintaining home ranges less than half the size of coyotes'. Foxes used fewer habitats than coyotes, their home ranges incorporating only open prairie, whereas coyote home ranges incorporated all habitat types in the study area, including river canyons, pinyon pine - juniper communities, and open plains.

In addition to the high degree of spatial overlap, we found no evidence of spatial-temporal avoidance of coyotes in foxes' movement patterns. Nocturnal and diurnal locations were analyzed separately to avoid the possibility that den use biased the analysis, that is, foxes entering dens to avoid coyotes rather than to move away from them. However, we found no evidence of spatial-temporal avoidance at any time during the day or night. If avoidance of coyotes is indeed absent from swift fox movement patterns, the potential for interference competition between the two species is increased. It is important to note the possibility, however, that spatialtemporal avoidance of coyotes may be occurring at a finer spatial or temporal scale than that at which the analysis could detect. For example, a fox may move away from a coyote only a short distance or for only a short period of time (White et al. 1995) to avoid an interaction with it.

Coyote-caused mortalities constituted at least $48 \%$ of fox deaths, indicating that interference competition was indeed 
Table 5. Percent occurrence of mammals of various sizes in the diets of coyotes and swift foxes on the Pinon Canyon Maneuver Site, Colorado, April 1997 - August 1998.

\begin{tabular}{|c|c|c|c|c|c|c|c|c|}
\hline \multirow[b]{2}{*}{ Season } & \multicolumn{4}{|l|}{ Coyote } & \multicolumn{4}{|l|}{ Swift fox } \\
\hline & $\begin{array}{l}\text { Cottontail } \\
\text { rabbit }\end{array}$ & $\begin{array}{l}\text { Black-tailed } \\
\text { jackrabbit }\end{array}$ & Ungulate & Rodent & $\begin{array}{l}\text { Cottontail } \\
\text { rabbit }\end{array}$ & $\begin{array}{l}\text { Black-tailed } \\
\text { jackrabbit }\end{array}$ & Ungulate & Rodent \\
\hline Dispersal & 27.4 & 29.0 & 6.5 & 37.1 & 22.7 & 2.7 & 4.0 & 70.7 \\
\hline Breeding & 32.0 & 17.5 & 4.1 & 46.4 & 22.6 & 1.7 & 0.9 & 74.8 \\
\hline Overall & 27.3 & 19.6 & 9.3 & 43.7 & 19.5 & 2.4 & 2.4 & 75.6 \\
\hline
\end{tabular}

Fig. 5. Causes of adult swift fox mortalities on the Pinon Canyon Maneuver Site, Colorado, in the pup-rearing (PR), breeding (BR), and dispersal (DI) seasons, April 1997 - August 1998.

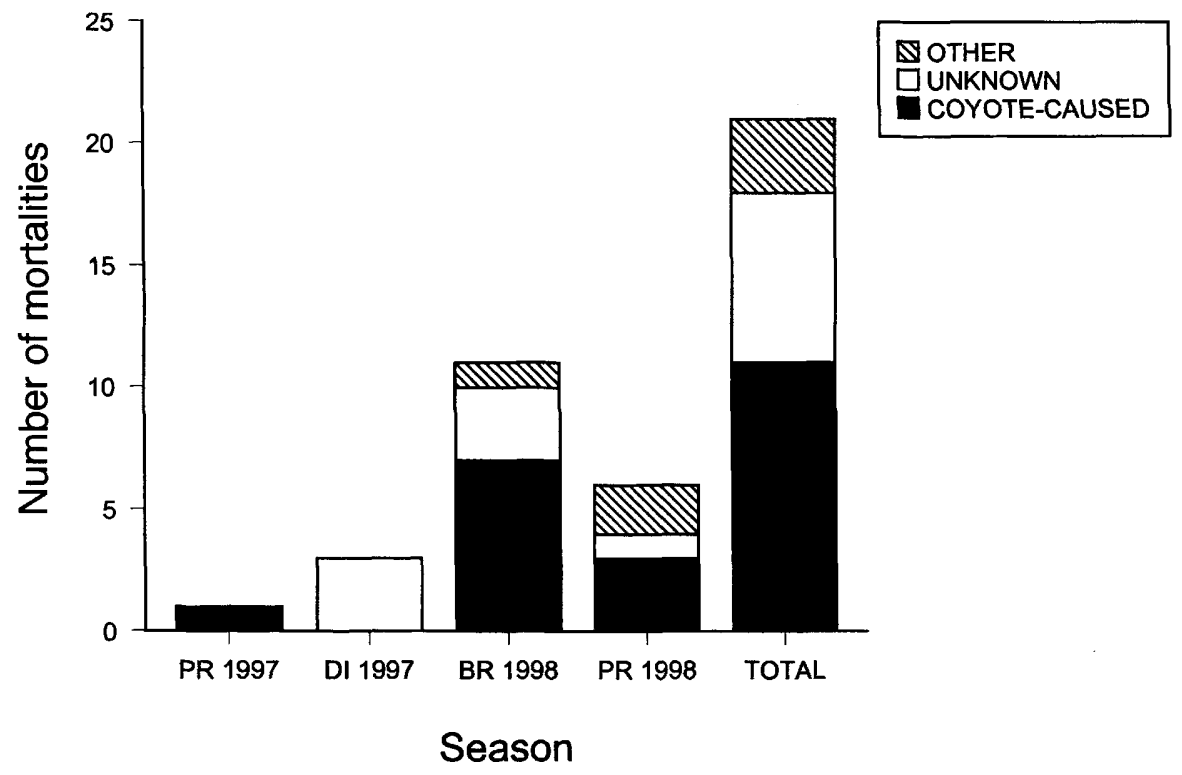

occurring. We believe that coyote-caused mortalities occurred as a result of interference competition rather than predation because, although occasional caching of fox carcasses was evident, the majority of carcasses were intact. This has been reported in studies of kit foxes (Disney and Spiegel 1992; Cypher and Spencer 1998), although Ralls and White (1995) found that coyotes on the Carrizo Plain Natural Area, California, fed on more than half of the kit foxes killed. High levels of coyote-caused mortalities have been reported in studies of swift fox and other fox species (Major and Sherburne 1987; Scott-Brown et al. 1987; Covell 1992; Carbyn et al. 1994; Cypher and Spencer 1998), although information on the significance of this mortality in regulating fox populations is scarce. White and Garrott (1997) analyzed the influence of coyote-caused mortalities on the population dynamics of kit foxes, using data from a number of studies. White and Garrott (1997) reported that the proportion of a fox population killed by coyotes increased linearly with fox density when fox densities were at low to moderate levels (insufficient data prohibited analysis at high fox densities), and thus coyote predation may be a major factor in population regulation. Further research (e.g., removal studies) is necessary to ascertain the impact of coyote-caused mortality on swift fox populations.

Coyotes and swift foxes also showed high indices of overlap of dietary resources. The two species utilized the same -prey items and varied the proportion of prey items consumed according to the season. Seasonal changes, and corresponding changes in prey abundance and availability of specific vegetation, have been shown to be significant factors determining coyote diets (Bowyer et al. 1983; Andelt et al. 1987). Similarly, evidence from studies reporting swift foxes as opportunistic feeders indicates that prey abundance is an important factor in swift fox prey use (Kilgore 1969; ScottBrown et al. 1987). Mammals were the primary prey item for both swift foxes and coyotes from November to July, and insects constituted the highest proportion of prey items in the diets of both species during August and September, when insects were at peak abundance.

Although the prey items utilized by coyotes and foxes were similar, the order of importance of these items in the diets of the two species differed. There was a significant difference between coyote and swift fox diets in all seasons, with each species exhibiting dietary specializations specific to the species. Juniper berries constituted a large portion of coyote diets during periods of availability (October-February) but were scarcely used by swift foxes. Because swift foxes avoid woodland habitat, juniper berries are not available to them as a food source. Swift foxes consumed higher proportions of insects (mainly Orthoptera) throughout the year. By comparing the proportions of different-sized mammals consumed, we found that compared with swift foxes, coyotes ate significantly more larger mammals (ungulates and leporids) than smaller mammals (rodents). It has been docu- 
Fig. 6. Distance from closest den in current use to locations of coyote-caused fox mortalities (A) and all fox locations (B) on the Pinon Canyon Maneuver Site, Colorado, April 1997 - August 1998.

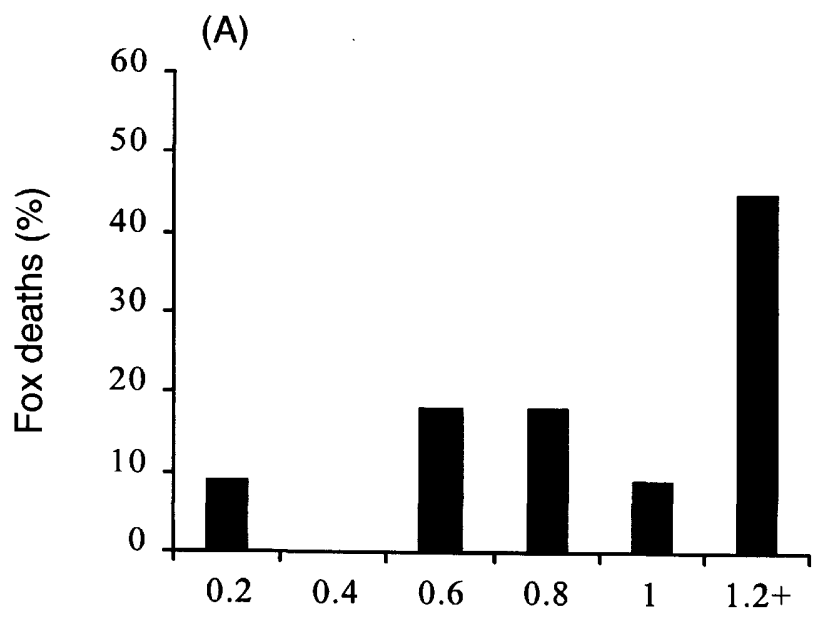

(B)

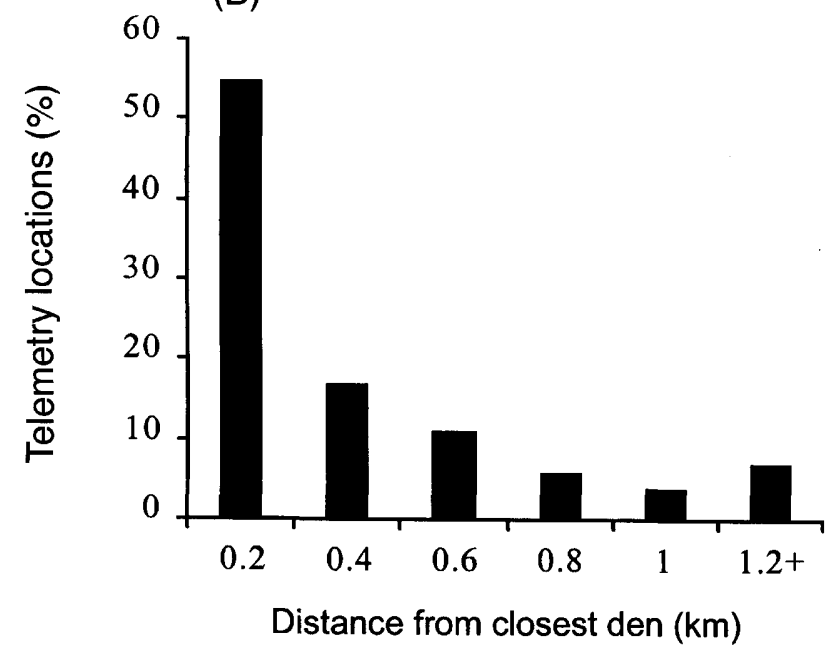

mented that coyotes also use larger prey items than other fox species (White et al. 1995; Cypher and Spencer 1998). This specialization in certain prey items likely reflects differences in body size, predatory ability, and energy needs between coyotes and swift foxes similar to those reported in studies of coyotes and other fox species (Major and Sherburne 1987; White et al. 1995).

The similarity of prey items utilized by coyotes and swift foxes indicates a potential for exploitative competition, although the specializations particular to each species and the seasonal differences observed for each canid indicate that the intensity of exploitative competition acting in the canid community may vary temporally. Indices of dietary overlap were lowest in the dispersal and breeding seasons, when coyotes consumed high proportions of juniper berries. When juniper berries were unavailable, the overlap increased. Temporal variations in overlap of other resources, as well as in behavior, may also affect the potential for competition between the species. For example, both species traveled greater distances in the breeding season than in any other season (also reported for the swift fox by Hines and Case 1991), increasing the potential for interference competition. This is supported by the fact that $58 \%$ (7/12) of coyote-caused mortalities occurred in the breeding season. Thus, seasonal changes in resource overlap and behavior can result in variation in the potential for both interference and exploitative competition between the two canid species.

The impact of a certain level of competition on a subdominant species can also vary. It has been hypothesized that the severity of the impact of coyotes on fox populations may be correlated with the status of the fox population (Ralls and White 1995). The impact may be greater during periods of low prey abundance or low reproduction rate in the fox population (Ralls and White 1995). Decreases in prey abundance can result in an increase in exploitative competition. In addition, prey scarcity may lead to an increased occurrence of interspecific interactions, and thus interference competition, owing to the increased rate of movement necessary for prey acquisition. Changes in resource availability can also influence the extent of competitive efficiency of one species over another. The greater dietary diversity of coyotes may increase their competitive advantage at times of low prey abundances. Coyotes had significantly larger home ranges than swift foxes in our study area and occupied home ranges that incorporated multiple habitat types, including river canyons, pinyon pine - juniper communities, and open plains. Coyotes are known to select habitats temporally, in accordance with prey densities (Murray et al. 1994), and in many areas will utilize human food sources (Todd 1985). Swift foxes exhibit less dietary diversity than coyotes and are more limited in their use of space and habitat, therefore they may be more affected by periods of low prey abundance.

Sympatric predators often share habitat and food resources in a similar manner to the two canid species in this study. Mechanisms that allow for sympatry in carnivores are complex and varied. Differences in size and physiological needs can allow predator species to coexist in the same area (Rosenzweig 1966). Various behavioral strategies can also be employed by species to facilitate coexistence with a dominant or predatory species. Strategies employed by subdominant species include predator avoidance, habitat-use partitioning, and prey-use partitioning. Frame (1986) proposed behavioral flexibility, such as the ability of leopards (Panthera pardus) to avoid cleptoparasitism by carrying food into trees, as the mechanism responsible for reducing competition among carnivores on the Serengeti Plains in Tanzania. In the same area, cheetahs (Acinonyx jubatus) are able to utilize areas with low prey density, allowing them to avoid the competitively dominant lions and hyenas in both time and space (Durant 1998). Thurber et al. (1992) reported a high degree of spatial overlap between coyotes and wolves on the Kenai Peninsula, Alaska, and proposed dietary partitioning as the mechanism that allows spatial sympatry between these two canids. Red foxes reduce competitive interactions with coyotes by spatial avoidance (Major and Sherburne 1987), but in doing so limit the resources available to them.

We found that swift foxes did not avoid coyote home ranges and were able to cohabit spatially with coyotes. We 
propose that the main strategies used by swift foxes are similar to those used by kit foxes (White et al. 1994): den use and some dietary partitioning. Den use was substantial, with foxes spending most diurnal hours in or on top of dens. The fact that all foxes confirmed or suspected of being killed by coyotes were located outside the $85 \%$ isopleth of the fox range and a substantial distance from their dens indicate that coyotes are more likely to attack a fox successfully when the fox is outside its denning area. This is further supported by the finding that locations of foxes were, on average, significantly closer to a den than the positions of coyote-killed foxes. Location of coyote-killed foxes on the boundary or outside the fox home range has also been documented for swift foxes in Kansas (Sovada et al. 1998). Species-specific dietary specializations were evident in all seasons and may also be an important mechanism allowing foxes to cohabit with coyotes. These mechanisms are effective in allowing established swift fox populations, such as the one in this study, to persist in sympatry with coyotes. However, with interference competition acting in conjunction with exploitative competition, coyotes could have a significant impact on swift fox populations that are declining or reestablishing.

\section{Acknowledgements}

Many thanks go to Cass Bromley, Linda Gorman, Chad Hamlin, Racheal Hare, Seija Karki, Mead Klavetter, Steve Langeland, Scott McLellan, Melissa Pangraze, Laurence Schafer, Laurie Schleub, Jen Stamp, Hilary Tall, and Whitney Weber for field assistance. Dan Sharps, Bruce Roselund, Gary Belew, Chris Bandy, and Tom Warren provided technical and logistical support. Funding and logistical support was provided by the U.S. Army, Directorate of Environmental Compliance and Management, Fort Carson, Colorado, the U.S. Fish and Wildlife Service, the Colorado Fish and Wildlife Assistance Office, Golden, Colorado, the Northern Prairie Science Center, Jamestown, North Dakota, the USDA National Wildlife Research Center, Logan, Utah, the Utah Cooperative Fish and Wildlife Research Unit, and Utah State University Presidential and Berryman Fellowships to the senior author. Research protocols were approved by Institutional Animal Care and Use Committees at the National Wildlife Research Center and Utah State University. We thank Barrie Gilbert and James Haefner for helpful comments on the manuscript.

\section{References}

Andelt, W.F., Kie, J.G., Knowlton, F.F., and Cardwell, K. 1987. Variation in coyote diets associated with season and successional changes in vegetation. J. Wildl. Manag. 51: 273-277.

Banfield, A.W.F. 1974. The mammals of Canada. University of Toronto Press, Buffalo, N.Y.

Barrett, M.W., Nolan, J.W., and Roy, L.D. 1982. Evaluation of a hand-held net-gun to capture large animals. Wildl. Soc. Bull. 10: 108-114.

Bowyer, R.T., McKenna, S.A., and Shea, M.E. 1983. Seasonal changes in coyote food habits as determined by fecal analysis. Am. Midl. Nat. 109: 266-273.
Carbyn, L.N. 1986. Some observations of the behavior of the swift foxes in reintroduction programs within the Canadian Prairies. Alberta Nat. 16: $37-41$.

Carbyn, L.N. 1987. Grey wolf and red wolf. In Wild furbearer management and conservation in North America. Edited by M. Novak, J.A. Baker, M.E. Obbard, and B. Malloch. Ontario Ministry of Natural Resources, Toronto, Ont. pp. 359-376.

Carbyn, L.N., Armbruster, H.J., and Mamo, C. 1994. The swift fox reintroduction program in Canada from 1983 to 1992. In Restoration of endangered species: conceptual issues, planning and implementation. Edited by M.L. Bowles and C.J. Whelan. Cambridge University Press, New York. pp. 247-271.

Case, T., and Gilpin, M. 1974. Interference competition and niche theory. Proc. Natl. Acad. Sci. U.S.A. 71: 3073-3077.

Colwell, R.K., and Futuyma, D.J. 1971. On the measurement of niche breadth and overlap. Ecology, 52: 567-576.

Covell, D.F. 1992. Ecology of the swift fox (Vulpes velox) in southeastern Colorado. M.S. thesis, University of Wisconsin, Madison.

Creel, S., and Creel, N.M. 1996. Limitation of African wild dogs by competition with larger carnivores. Conserv. Biol. 10: 526-538.

Cypher, B.L., and Scrivner, J.H. 1992. Coyote control to protect endangered San Joaquin kit foxes at the Naval Petroleum Reserves, California. In Proceedings of the 15th Vertebrate Pest Conference, Newport Beach, Calif., 3-5 March 1992. Edited by J.E. Borrecco and R.E. Marsh. University of California, Davis. pp. $42-47$.

Cypher, B.L., and Spencer, K.A. 1998. Competitive interactions between coyotes and San Joaquin kit foxes. J. Mammal. 79: 204-214.

Disney, M., and Spiegel, L.K. 1992. Sources and rates of San Joaquin kit fox mortality in western Kern County, California. Trans. West. Sect. Wildl. Soc. 28: 73-82.

Durant, S.M. 1998. Competition refuges and coexistence: an example from Serengeti carnivores. J. Anim. Ecol. 67: 370-386.

Eberhardt, L.E., Hanson, W.C., Bengtson, J.L., Garrot, R.A., and Hanson, E.E. 1982. Arctic fox home-range characteristics in an oil-development area. J. Wildl. Manag. 46: 183-190.

Egoscue, H.G. 1979. Vulpes velox. Mammal. Species, 122: 1-5.

Frame, G.W. 1986. Carnivore competition and resource use in the Serengeti ecosystem of Tanzania. Ph.D. thesis, Utah State University, Logan.

Fuller, T.K., and Keith, L.B. 1981. Non-overlapping ranges of coyotes and wolves in northeastern Alberta. J. Mammal. 62: 403-405.

Gese, E.M., and Rongstad, O.J. 1989. The ecology of coyotes on the Pinon Canyon Maneuver Site, Colorado 1983-1988. Final Report. U.S. Army, Directorate of Environmental Compliance and Management, Fort Carson, Colo.

Gese, E.M., Rongstad, O.J., and Mytton, W.R. 1987. Manual and net-gun capture of coyotes from helicopters. Wildl. Soc. Bull. 15: 444-445.

Gese, E.M., Rongstad, O.J., and Mytton, W.R. 1988a. Home-range and habitat use of coyotes in southeastern colorado. J. Wildl. Manag. 52: 640-646.

Gese, E.M., Rongstad, O.J., and Mytton, W.R. 1988b. Relationship between coyote group size and diet in southeastern colorado. J. Wildl. Manag. 52: 647-653.

Gese, E.M., Rongstad, O.J., and Mytton, W.R. 1989. Population dynamics of coyotes in southeastern colorado. J. Wildl. Manag. 53: $174-181$.

Gese, E.M., Andersen, D.E., and Rongstad, O.J. 1990. Determining home-range size of resident coyotes from point and sequential locations. J. Wildl. Manag. 54: 501-506. 
Gier, H.T. 1968. Coyotes in Kansas. Kans. State Coll. Agric. Exp. Stn. Bull. No. 393.

Harrison, D.J., Bissonette, J.A., and Sherburne, J.A. 1989. Spatial relationships between coyotes and red foxes in eastern Maine. J. Wildl. Manag. 53: 181-185.

Henke, S.E. 1992. Effect of coyote removal on the faunal community ecology of a short-grass prairie. Ph.D. thesis, Texas Tech University, Lubbock.

Hines, T.D., and Case, R.M. 1991. Diet, home range, movements and activity periods of swift fox in Nebraska. Prairie Nat. 23: 131-138.

Horn, H.S. 1966. Measurement of "overlap" in comparative ecological studies. Am. Nat. 100: 419-424.

Kie, J.G., Baldwin, J.A., and Evars, C.J. 1996. Calhome: a program for estimating animal home ranges. Wildl. Soc. Bull. 24: 342-344.

Kilgore, D.L. 1969. An ecological study of the swift fox (Vulpes velox) in the Oklahoma Panhandle. Am. Midl. Nat. 81: 512-533.

Kruuk, H. 1972. The spotted hyena: a study of predation and social behavior. University of Chicago Press, Chicago.

Linhart, S.B., and Robinson, W.B. 1972. Some relative carnivore densities in areas under sustained coyote control. J. Mammal. 53: $880-884$.

Major, J.T., and Sherburne, J.A. 1987. Interspecific relationships of coyotes, bobcats and red foxes in western Maine. J. Wildl. Manag. 51: 606-616.

Martin, A.C., Gensch, R.H., and Brown, C.P. 1946. Alternative methods in upland gamebird food analysis. J. Wildl. Manag. 10: $8-12$.

Mech, L.D. 1983. Handbook of animal radiotracking. University of Minnesota Press, Minneapolis.

Mills, M.G.L., and Biggs, H.C. 1993. Prey apportionment and related ecological relationships between large carnivores in Kruger National Park. Symp. Zool. Soc. Lond. No. 65. pp. 253-268.

Moore, T.D., Spencer L.E., and Dugnolle, C.E. 1974. Identification of the dorsal guard hairs of some mammals of Wyoming. Wyo. Game Fish Dep. Bull. No. 14.

Murray, D.L., Boutin, S., and O'Donoghue, M. 1994. Winter habitat selection by lynx and coyotes in relation to snowshoe hare abundance. Can. J. Zool. 72: 1444-1451.

Polis, G.A., Meyers, C.A., and Holt, R.D. 1989. The ecology and evolution of intraguild predation: potential competitors that eat each other. Annu. Rev. Ecol. Syst. 20: 297-330.

Ralls, K., and White, P.J. 1995. Predation on San Joaquin kit foxes by larger canids. J. Mammal. 76: 723-729.

Rongstad, O.J., Laurion, T.R., and Andersen, D.E. 1989. Ecology of swift fox on the Pinon Canyon Maneuver Site, Colorado. Final report, Directorate of Engineering and Housing, Fort Carson, Colo.

Rosenzweig, M.L. 1966. Community structure in sympatric Carnivora. J. Mammal. 47: 602-612.

Sargeant, A.B., and Allen, S.H. 1989. Observed interactions between coyotes and red foxes. J. Mammal. 70: 631-633.
Sargeant, A.B., Allen, S.H., and Hastings, J.O. 1987. Spatial relations between sympatric coyotes and red foxes in North Dakota. J. Wildl. Manag. 51: 285-293.

SAS Institute Inc. 1988. SAS/STAT ${ }^{\text {TM }}$ user's guide, version 6.12 ed. SAS Institute Inc., Cary, N.C.

Schoener, T.W. 1974. Resource partitioning in ecological communities. Science (Washington, D.C.), 185: 27-39.

Scott-Brown, J.M., Herrero, S., and Reynolds, J. 1987. Swift fox. In Wild furbearer management and conservation in North America. Edited by M. Novak, J.A. Baker, M.E. Obbard, and B. Malloch. Ontario Ministry of Natural Resources, Toronto, Ont. pp. 432-441.

Shaw, R.B., Anderson, S.L., Schulz, K.A., and Diersing, V.E. 1989. Plant communities, ecological checklist, and species list for the U.S. Army Pinon Canyon Maneuver Site, Colorado. Colo. State Univ. Sci. Ser. No. 37.

South Dakota Department of Game, Fish and Parks. 1998. Conservation assessment and conservation strategy for swift fox in the United States. South Dakota Department of Game, Fish and Parks, Pierre.

Sovada, M.A., Roy, C.C., Bright, J.B., and Gillis, J.R. 1998. Causes and rates of mortality of swift foxes in western Kansas. J. Wildl. Manag. 62: 1300-1306.

Thurber, J.M., Peterson, R.D., Woolington, J.D., and Vucetich, J.A. 1992. Coyote coexistance with wolves on the Kenai Peninsula, Alaska. Can. J. Zool. 70: 2494-2498.

Todd, A.W. 1985. Demographic and dietary comparisons of forest and farmland coyote, Canis latrans, populations in Alberta. Can. Field-Nat. 99: 163-171.

Trent, T.T., and Rongstad, O.J. 1974. Home-range and survival of cottontail rabbits in southwestern Wisconsin. J. Wildl. Manag. 38: $459-472$.

Voigt, D.R., and Earle, B.D. 1983. Avoidance of coyotes by red fox families. J. Wildl. Manag. 47: 852-857.

Weaver, J.L., and Hoffman, S.W. 1979. Differential detectability of rodents in coyote scats. J. Wildl. Manag. 43: 783-786.

White, G.C., and Garrott, R.A. 1990. Analysis of radio-tracking data. Academic Press, New York.

White, P.J., and Garrott, R.A. 1997. Factors regulating kit fox populations. Can. J. Zool. 75: 1982-1988.

White, P.J., Ralls, K., and Garrott, R.A. 1994. Coyote - kit fox interactions as revealed by telemetry. Can. J. Zool. 72: 18311836.

White, P.J., Ralls, K., and Vanderbilt White, C.A. 1995. Overlap in habitat and food use between coyotes and San Joaquin kit foxes. Southwest. Nat. 40: 342-349.

Wooding, J.B. 1984. Coyote food habits and the spatial relationship of coyotes and foxes in Mississippi and Alabama. M.S. thesis, Mississippi State University, Starkville.

Worton, B.J. 1989. Kernal methods for estimating the utilization distribution in home-range studies. Ecology, 70:164-168. 